\title{
Expression and Purification of Recombinant Human Amelogenin Using the Prokaryotic Expression System
}

\author{
Xiaoyun Feng ${ }^{1}$, Jing $\mathrm{Yao}^{2}$, Qin $\mathrm{Du}^{2}$, Xiaohua Ren ${ }^{2}$ and Kun Tian ${ }^{1,2, *}$ \\ ${ }^{1}$ Department of Biomedical Engineering, Medical School of University of Electronic Science and Technology of China, Chengdu, \\ Sichuan 610054, P.R. China. \\ ${ }^{2}$ Department of Stomatology, Sichuan Academy of Medical Science and Sichuan Provincial People's Hospital, Chengdu, Sichuan \\ 610072, P.R. China \\ *Corresponding author
}

\begin{abstract}
The amelogenins (Am) constitute about $90 \%$ of the enamel matrix proteins and play a critical role in enamel biomineralization. This study aimed to express and characterize recombinant human amelogenin (rAm) protein in the prokaryotic expression system in quantities sufficient for structural and functional research. Human cDNA coding for a 175 amino acid amelogenin protein was subcloned into the pET-28a(+) vector, this system adds a hexa-histidine tag to $\mathrm{N}$-terminal amino acid of the expressed protein, enabling effective three steps purification by $\mathrm{Ni}^{2+-} \mathrm{NTA}$ affinity chromatography, an anion-exchange resource $Q$ packed column, and Superdex 200 10/300 GL gel filtration resin. The recombinant protein was expressed in E. coli BL21 cells and the yield of purification his-tagged human amelogenin was up to $19 \mathrm{mg} / \mathrm{L}$ culture. Recombinant human amelogenin (rAm) was characterized by SDS-PAGE and Coomassie brilliant blue R-250. Production of significant amounts of pure, full-length amelogenin opened up the possibility to investigate novel functions of amelogenin. Their chemical structure, self- assembly and amelogenin-mineral interactions play a key role in the regulation of enamel mineralization process.
\end{abstract}

Keywords-recombinant huamn amelogenin; E. coli BL21 cells; purification; SDS-PAGE

\section{INTRODUCTION}

Tooth enamel, the most mineralized tissue in the body, is formed by an evolutionarily highly conserved process that is controlled by extracellular matrix proteins [1]. During the secretory stage of enamel formation, the three major proteins secreted by ameloblasts are amelogenin (Am), ameloblastin and enamelin [2]. Upon secretion from ameloblasts, the enamel matrix proteins assemble to facilitate crystal nucleation and growth in appropriate physico-chemical microenvironment [1]. The amelogenins constitute about $90 \%$ of the enamel matrix proteins and play an important role in enamel biomineralization [3]. Moreover, they are hydrophobic molecules that self-assemble into nanosphere structures, which are thought to be involved in regulating the ultra -structural organization of the developing enamel crystallite [4-5].

During enamel development and mineralization, the secreted amelogenins are lost from the tissue,along with most of the other enamel matrix proteins, due to sequential degradation by specific proteases such as enamelysin (matrix metalloproteinase 20,Mmp-20) and kallikrein 4 (Klk4) [6]. They are replaced by mineral ions, calcium, and phosphorus, which eventually results in fully mineralized, hard, and mature enamel [7-9]. The human amelogenin gene are has been mapped to Xp22.1-p22.3 and Yp11.2 with 90\% of the transcripts expressed from the X-chromosome and $10 \%$ from the Y-chromosome [10-11]. Mutations in the X-chromosomal copy of the amelogenin gene have been associated with the hereditary disease amelogenesis inperfecta, which illustrates the importance of amelogenin in developing enamel [12]. Furthermore, the amelogenins were also thought to be tissue-specific and exclusively expressed by the enamel producing ameloblast cells [13], however, various isoforms have since been found in the dentin matrix [14] and the associated odontoblast cells [15]. The production of recombinant proteins free of other matrix elements is a valuable tool to investigate which components are responsible for the regeneration and amelogenin was suggested to be such a candidate. In addition, low molecular mass amelogenin polypeptides have since been associated with cell signaling and have been suggested to have osteogenic potential [16-17].

The described heterogeneity of the matrix makes isolation and purification of sufficiently large quantities of any one of the amelogenin isoforms from the developing tissue, extremely challenging [3]. This problem has been previously overcome by high expression of mouse amelogenin [18], porcine amelogenin [19] and human amelogenin [20] in prokaryotic bacterial systems. In this research, we describe the expression of a recombinant human amelogenin protein in the prokaryotic bacterial systems, which has made possible the investigation of novel functions of amelogenin by providing relatively high amounts of pure amelogenin, free from contamination of other enamel matrix proteins.

\section{MAterials AND METHODS}

\section{A. RNA Isolation and RT-PCR Analyses}

The tooth germs of mandibular third molar which was in enamel developmental stages from patient who will accept orthodontic treatment were dissected and fixed with $4 \%$ paraformaldehyde in PBS at $4^{\circ} \mathrm{C}$ overnight. Dental sac were 
decalcified at $4{ }^{\circ} \mathrm{C}$ in a $10 \%(\mathrm{w} / \mathrm{v}) \mathrm{Na}^{2+}$-EDTA solution $(\mathrm{pH} 7.0)$ for 10 days with daily solution changes, and paraffin samples were prepared as described [24]. Total RNA from the tooth germs of mandibular third molar which was in enamel developmental stages was isolated using Trizol Reagent (Invitrogen). According to the manufacturer's specifications, RNAs were purified using the DNA Purification Kit (Tiangen biotech, Beijing) in order to get rid of organic components, and converted into cDNA (M-MLV Reverse Transcriptase, Takara) using Amelogenin primers.

\section{B. Construction of the Recombinant Plasmid Expressing Amelogenin}

PCR primers were designed with Primer3 (http://bioinfo. ut.ee/primer3/;) and synthesized by Sangon (China) (Am-F:CGCGGATCCATGGGGACCTGGATTTT; Am-R:CGAGCTCTTAATCCACTTCCTCCCGC). PCR amplification was performed by Bio-RAD S1000 Thermal Cycler (BIO-RAD, USA) using Pfu DNA polymerase (TransGen Biotech, Beijing), as previously described [8]. The PCR fragment was digested with Bam HI and SacI and ligated into pET-28a (+) vector (Invitrogen) linearized with Bam HI and SacI and dephosphorylated by calf intestine alkaline phosphatase. The ligation mixture were chemically trans -formed into the competent E. Coli DH5 $\alpha$ and cultured at $37^{\circ} \mathrm{C}$ in LB agar with kanamycin $(0.1 \mathrm{mg} / \mathrm{ml})$ for selection of the recombinants. After confirmed by DNA sequencing, the recombinant plasmid was transformed into E. Coli BL21 (DE3) for proteinexpression.

\section{Expression and Purification of Amelogenin in E. Coli BL21}

The over-expression of rAm in E. coli BL21 cells was induced as previously described [10]. rAm were grown at $37^{\circ} \mathrm{C}$ in $1 \mathrm{~L}$ of $\mathrm{LB}$ medium supplemented with $0.1 \mathrm{mg} / \mathrm{ml}$ kanamycin to OD600 0.6. Protein expression was induced by the addition of $0.2 \mathrm{mM}$ IPTG and the culture was incubated for overnight at $16^{\circ} \mathrm{C}$. Expressed fusion protein was analyzed on a $12 \%$ SDS-PAGE gel. The cells were collected by centrifugation for $30 \mathrm{~min}$ at 5,000 $\mathrm{g}$ and re-suspended in $50 \mathrm{ml}$ ultrasonication buffer $(500 \mathrm{mM}$ NaCL, $25 \mathrm{mM}$ Tris, $20 \mathrm{mM}$ imidazole, $\mathrm{PH} 8.0$ ) and sonicated at $500 \mathrm{~W}, 3 \mathrm{~s}$ pulse and $3 \mathrm{~s}$ rest on ice for a cycle for $40 \mathrm{~min}$ (Scientz JY92-2D, China). Following centrifugation at $18,000 \mathrm{~g}$ for $30 \mathrm{~min}$, the supe -rnatant that the poly-His tagged proteins were purified by affinity chromatography from crude cell extracts on a nickel-nitrilotriacetic acid (Ni2+-NTA) agarose column (Haiji biotech, Beijing). Elution was carried out in the presence of an imidazole gradient concentration $(50 \sim 500 \mathrm{mmol} / \mathrm{L})$ and was collected per millitre, and A 280 was measured. The eluted protein was loaded onto an anion-exchange Resource Q packed column (GE Healthcare), which was pre-equilibrated with Buffer A (50mM NaCl, 25mM Tris-HCl PH 8.0). Sample was loaded at a rate of $0.5 \mathrm{~mL} / \mathrm{min}$ and the column was washed with two bed volumes of Buffer A. Finally, the column bound proteins were eluted using a programmed gradient of Buffer B (1M NaCl, 25mM Tris-HCl PH 8.0). The cleavage fragment was removed by using Superdex 200 10/300 GL gel filtration resin (pharmacia). The column was pre-equilibrated with $100 \mathrm{mM} \mathrm{NaCl}$ buffer( $100 \mathrm{mM} \mathrm{NaCl}, 25 \mathrm{mM}$ Tris-HCl PH 8.0) and rAm proteins were eluted by this buffer. SDS-PAGE was performed using $12 \%$ running gel on the GelDoc XR System (Bio-Rad). Briefly, the protein samples were loaded on the gel, which was electrophoresed at $120 \mathrm{~V}$ for $1 \mathrm{~h}$ and stained with Coomassie brilliant blue R-250.

\section{RESULTS}

\section{A. RNA Isolation and RT-PCR Analyses}

RNA analyzed on a nondenaturing $1 \%$ agarose gel. The RNA was visualized with ethidium bromide present in the gel (Figure1(A)). The value of A260 / A280 and A260 / A230 were 1.99 and 2.08 ,respectively. The brightness of $28 \mathrm{~S}$ strips is two times the brightness of $18 \mathrm{~S}$ strip. The results show that high quality RNA has been extracted and can be used for the full length amelogenin gene amplification. The PCR products were resolved on $1 \%$ agarose gels and stained with ethidium bromide. The amelogenin primers produced a band at 576 bp(Figure1(B))

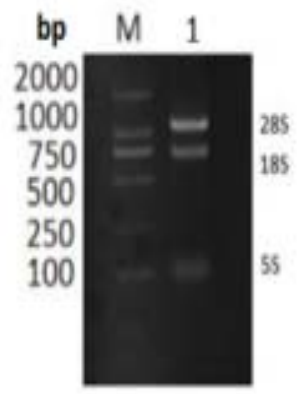

A

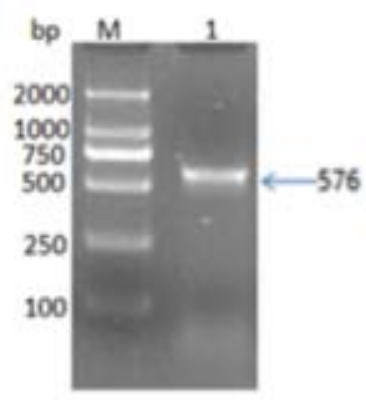

B
FIGURE I. (A)RNA EXTRACTED FROM THE TOOTH GERMS OF MANDIBULAR THIRD MOLAR WHICH WAS IN ENAMEL DEVELOPMENTAL STAGES. M, RNA SIZE MARKERS; LANE 1, RNA EXTRACTED FROM TOOTH GERMS OF MANDIBULAR THIRD MOLAR. (B) RT-PCR ANALYSIS OF MRNA THAT WERE EXTRACTED WITH TRIZOL REAGENT. M, DM2000 DNA MAKER; LANE 1, AMELOGENIN (576 BP) CDNAS AMPLIFIED BY RT-PCR

\section{B. Expression and Characterization of rAm Protein in E.Coli}

E. coli transformed by pET28a (+)-rAm plasmid were cultured in LB medium at $37^{\circ} \mathrm{C}$ and IPTG $(0.2 \mathrm{mmol} / \mathrm{L})$ was added when the culture reached the OD600 of 0.6 to induce expression of rAm. Bacteria was collected both prior to and post IPTG induction. The expression of $28 \mathrm{kDa}$ protein was induced as revealed by Coomassie brilliant blue R-250 staining of the protein gel separated by SDS-PAGE (Figure 2(A), Lane 1, 2). After IPTG induction, the bacteria containing rAm was sonicated, total bacterial protein (Figure 2(A), Lane 3 ), soluble cell lysate (Figure 2(A), Lane 4) and inclusion bodies (Figure 2(A), Lane 5) were analyzed by SDS-PAGE and protein staining. A band of approximately $28 \mathrm{kDa}$ was observed in supernatant of $\mathrm{E}$. coli lysate following ultrasonication of the induced E. coli. (Figure 2(A), Lane 4), which is close to the calculated molecular weight of rAm, that represented $71 \%$ of the total protein in the soluble cell lysate measured by densitometry scanning of the stained gel. 

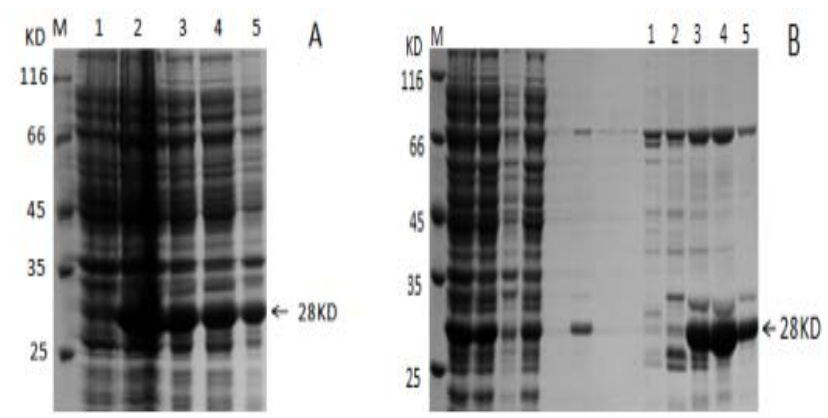

FIGURE II. (A) EXPRESSION OF RAM IN E. COLI BL21 (DE3). LANE M: PROTEIN MARKERS; LANE 1: UN-INDUCED E. COLI CELL

LYSATE; LANE 2: E. COLI LYSATE AFTER IPTG INDUCTION; LANE 3: TOTAL BACTERIAL PROTEIN OF E. COLI LYSATE AFTER ULTRASONICATION OF THE INDUCED E. COLI; LANE 4: THE SUPERNATANT OF E. COLI LYSATE AFTER ULTRASONICATION OF THE INDUCED E. COLI; LANE 5: THE PELLET FRACTION OF THE ULTRASONICATION OF THE INDUCED E. COLI. (B) RAM PROTEIN PURIFIED BY NI-NTA AGAROSE COLUMN AFFINITY

CHROMATOGRAPHY WAS ELUTED BY AN IMIDAZOLE GRADIENT CONCENTRATION (50 300 MMOL/L).LANE M: PROTEIN MARKERS; LANE1-5: THE ELUTED PROTEIN BY AN IMIDAZOLE

CONCENTRATION (50, 100, 150, 200, 300 MMOL/L, RESPECTIVELY)

\section{Purification and Characterization of rAm Protein in E.Coli}

Am proteins were purified by affinity chromatography $\left(\mathrm{Ni}^{2+-} \mathrm{NTA}\right)$ and eluted by an imidazole gradient concentration $(50 \sim 300 \mathrm{mmol} / \mathrm{L})$. The eluted protein was analyzed on a $12 \%$ SDS-PAGE gel (Figure 2(B)). Base on the isoelectric point value of $\mathrm{rAm}(\mathrm{pI}=5.3)$, Anion exchange is more appropriate for $\mathrm{rAm}$ protein than cation exchange. The eluted protein was loaded onto an anion-exchange Resource $\mathrm{Q}$ packed column. The chromatography buffer was optimized to Buffer A in accordance to batch absorption/elution matrix experiments. For Resource Q chromatography, Buffer A was used to equilibrate the column prior to loading the refolded protein solution, as well as washing buffer to remove the unbound contaminants following the loading process. The recombinant protein was eluted by high salt gradient elution method, which was introduced from Buffer B. One protein peak monitored at OD280 was observed (Figure 3). The cleavage fragment was removed by using Superdex 75 10/300 GL gel filtration resin. SDS-PAGE was performed using 12\% running gel for purified rAm protein analysis (Figure 4). Protein quantification was estimated using the Bradford method [14]. The ratio of Am to the total proteins was obtained by SDS-PAGE and the corresponding protein bands were measured using the gel-analysis tool BandScan 5.0 software. We obtained about $19 \mathrm{mg}$ of soluble purified Am protein from $1 \mathrm{~L}$ of flask culture broth, which would be more than $86 \%$ of purification yield.

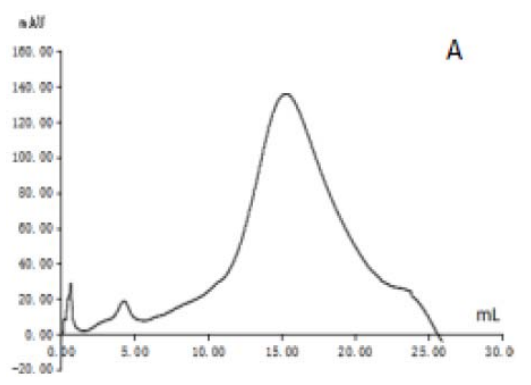

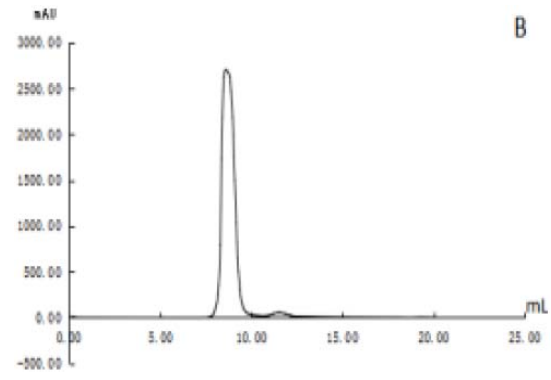

FIGURE III. (A) PURIFICATION PROFILE OF RAM USING RESOURCE Q COLUMN BY AKTA PRIME PLUS SYSTEM. UV ABSORBANCE AT 280 NM AND CONDUCTIVITY WERE DETECTED DURING THE ELUTION PROCESS. ONE PROTEIN ELUTION PEAK WAS OBSERVED. (B) PURIFICATION PROFILE OF RAM USING SUPERDEX 200 10/300 GL GEL FILTRATION RESIN (PHARMACIA) BY AKTA PRIME PLUS SYSTEM. UV ABSORBANCE AT 280 NM AND CONDUCTIVITY WERE DETECTED DURING THE ELUTION PROCESS. ONE PROTEIN ELUTION PEAK WAS OBSERVED
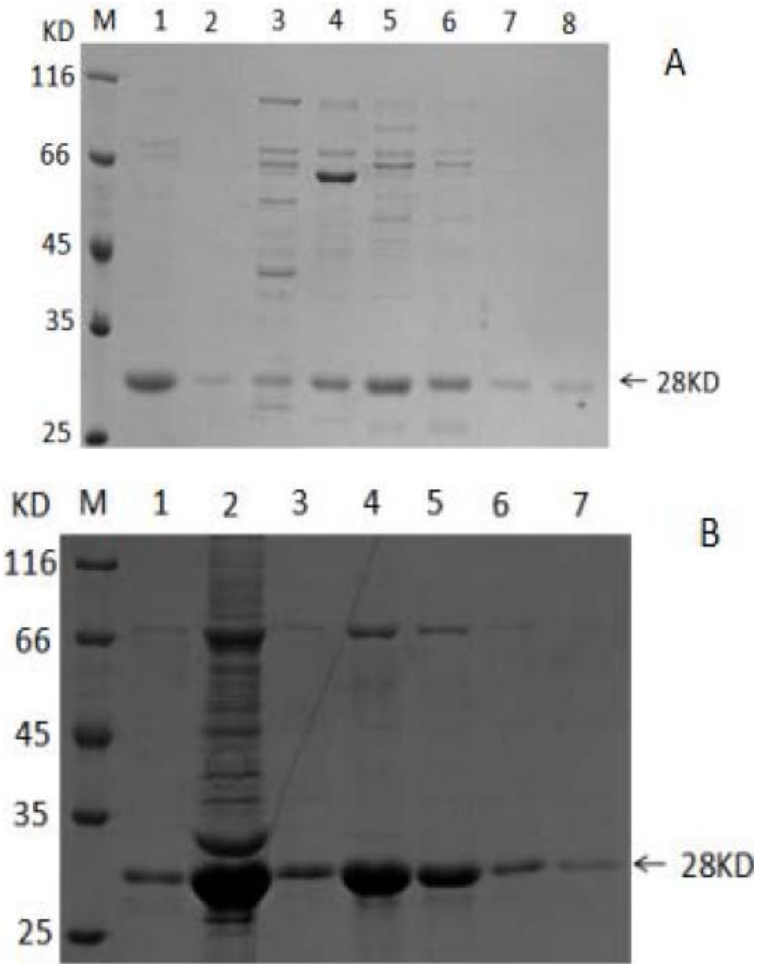

FIGURE IV. (A) PURIFIED RAM USING RESOURCE Q COLUMN BY AKTA PRIME PLUS SYSTEM IN 12\% SDS-PAGE GEL. M: PROTEIN MARKER LINE 1: RAM PROTEIN PURIFIED BY NI-NTA AGAROSE COLUMN AFFINITY CHROMATOGRAPHY; LINE 2-8: RAM PROTEIN WAS ELUTED BY HIGH SALT GRADIENT ELUTION METHOD. (B) PURIFIED RAM USING SUPERDEX 75 10/300 GL BY AKTA PRIME PLUS SYSTEM IN $12 \%$ SDS-PAGE GEL. M: PROTEIN MARKER LINE 1: RAM PROTEIN PURIFIED BY NI-NTA AGAROSE COLUMN AFFINITY CHROMATOGRAPHY; LINE 2: RAM PROTEIN PURIFIED BY RESOURCE Q COLUMN BY AKTA PRIME PLUS SYSTEM ; LINE 3-7: RAM PROTEIN WAS ELUTED BY 100MM NACL BUFFER.

\section{DISCUSSION}

Although the spatial structure of amelogenin is unknown, scientists still hypothesized the possible array mode of Am molecular through its amphiphilic sequence. Amelogenin is a hydrophobic enamel matrix protein that possesses the unique 
physiological characteristic of self-aggregation into nano -spheres, an important structural feature related to its function in the developing enamel; but one that makes it challenging to express, isolate, and analyze [3]. Expression of a recombinant amelogenin protein has been reported in prokaryotic systems mostly [18-21]. These recombinant amelogenin proteins have been used in various structural and functional studies [23]. We has performance the express of a recombinant human amelogenin protein in E. coli BL21 cells using the prokaryotic expression system. This histidine-tagged system enabled high purification through three steps isolation. The yield of purified protein was $19 \mathrm{mg} / \mathrm{L}$ culture of mainly full-length protein. Application a mixture of many enamel matrix proteins and their degradation products, to tooth root surfaces in sites of diseased periodontium has been shown to promote the regeneration of all the periodontal tissues [8]. Although, it was not clear which of the proteins comprising the extracellular matrix is responsible for the regeneration. The availability of substantial amounts of purified recombinant human amelogenin expressed in E. coli BL21 cells provides a valu -able and reproducible source of biologically active human amelogenin protein. This recombinant protein is currently being used to study the underlying mechanisms associated with the functions of the human amelogenin protein in normal, diseased, and regenerating periodontal tissues and other mineralizing tissues.

\section{ACKNOWLEDGEMENT}

This work was supported by grant from National Natural Science Foundation of China: Controlled synthesis of enamel like hydroxyapatite on bio-modified macromolecule template (No.81100786) and Key Technology Research and Development Program of the of SiChuan Province, China: Application on rapid mineralization of enamel superficial defect(2013SZ0020).

\section{REFERENCES}

[1] H. H. Ravindranath, L. S. Chen, M. Zeichner-David, R. Ishima, R. M. H. Ravindranath, Interaction between the enamel matrix proteins amelogenin and ameloblastin, Biochemical and Biophysical Research Communication, 2004, 323: 1075-1083.

[2] C. C. Hu, M. U. Fukae, T. Chida, Cloning and characterization of porcine enamelin mRNAs. J. Dent. Res, 1997, 76: 1720-1729.

[3] A. L.Taylor, A. H. Haze-Filderman, A. Blumenfeld, High yield of biologically recombinant human amelogenin using the baculovirus expression system. Protein Expression and Purification, 2006, 45: 43-53.

[4] A. G. Fincham, J. Moradian-Oldak, J. P. Simmer, P. Sarte, E. C. Lau, T. Diekwisch, H. C. Slavkin, Self-assembly of a recombinant amelogenin protein generates supramolecular structures, J. Struct. Biol, 1994, 112: 103-109.

[5] A. G. Fincham, J. P. Simmer, Amelogenin proteins of developing dental enamel, Ciba Found Symp, 1997, 205: 118-134.

[6] J. D. Bartlett, J. P. Simmer, J. Xue, H. C. Margolis, E. C. Moreno, Molecular cloning and mRNA tissue distribution of a novel matrix metalloproteinase isolated from porcine enamel organ. Gene, 1996, 183: 123-128.

[7] C. Robinson, S. J. Brookes, R. C. Shore, J. Kirkham, The developing enamel matrix: nature and function, Eur. J. Oral Sci, 1998, 1: 282-291.

[8] D. Deutsch, J. Catalano-Sherman, L. Dafni, S. David, A. Palmon, Enamel matrix proteins and ameloblast biology, Connect. Tissue Res, 1995, 32: 97-107.

[9] C. E. Smith, Cellular and chemical events during enamel maturation, Crit. Rev. Oral Biol. Med, 1998, 9: 128-161.
[10] E. C. Lau, T. K. Mohandas, L. J. Shapiro, H. C. Slavkin, M. L. Snead, Human and mouse amelogenin gene loci are on the sex chromosomes, Genomics, 1989, 4: 162-168.

[11] E. C. Salido, H. Y. Paulie, K. Koprivnikar, L. C. Yu, L. Shapiro, The human enamel proteingene amelogenin is expressed from both the $\mathrm{X}$ and the Y chromosomes, Am. J. Hum. Genet, 1992, 50 : 303-316.

[12] P. S. Hart, T. C. Hart, J. P. Simmer, J. T. Wright, A nomenclature for X-linked amelogenesis imperfecta, Arch. Oral Biol, 2002, 47: 255-260.

[13] P. Adeleke-Stainback, E. Chen, P. Collier, Z. A. Yuan, R. Piddington, S. Decker, J. Rosenbloom, C. W. Gibson, Analysis of the regulatory region of the bovine X-chromosomal amelogenin gene, Connect. Tissue Res, 2005, 32: 115-118

[14] D. R. Nebgen, H. Inoue, B. Sabsay, K. Wei, C. S. Ho, A. Veis, IdentiWcation of thechondrogenic-inducing activity from bovine dentin (bCIA) as a low-molecular-mass amelogenin polypeptide, J. Dent. Res, 1999, 78: 1484-1494.

[15] S. Oida, T. Nagano, Y. Yamakoshi, H. Ando, M. Yamada, M. Fukae, Amelogenin gene expression in porcine odontoblasts, J. Dent. Res, 2002, 81: 103-108.

[16] A. Veis, K. Tompkins, K. Alvares, K. Wei, L. Wang, X. S. Wang, A. G. Brownell, S. M. Jengh, K. E. Healy, SpeciWc amelogenin gene splice products have signaling eVects on cells in culture and in implants in vivo, J. Biol. Chem, 2000, 275: 41263-41272.

[17] A. Veis, Amelogenin gene splice products: potential signaling molecules, Cell Mol. Life Sci, 2003, 60: 38-55.

[18] J. P. Simmer, E. C. Lau, C. C. Hu, T. Aoba, M. Lacy, D. Nelson, M. Zeichner-David, M. L. Snead, H. C. Slavkin, A. G. Fincham, Isolation and characterization of a mouse amelogenin expressed in Escherichia coli, Calcif. Tissue Int, 1994, 54: 312-319.

[19] O. H. Ryu, A. G. Fincham, C. C. Hu, C. Zhang, Q. Qian, J. D. Bart- lett, J.P. Simmer, Characterization of recombinant pig enamelysin activity and cleavage of recombinant pig and mouse amelogenins, J. Dent. Res, 1999, 78: 743-750.

[20] D. Deutsch, E. Chityat, M. Hekmati, A. Palmon, Y. Farkash, L. Dafni, High Expression of Human Amelogenin in E. coli., Adv. Dent. Res, 1996, 10: 187-194.

[21] W. Li, C. Gao, Y. Yan, P. DenBesten, X-linked amelogenesis imperfecta may result from decreased formation of tyrosine Wch amelogenin peptide (TRAP), Arch. Oral Biol, 2003, 48: 177-183.

[22] J. D. Termine, A. B. Belcourt, P. J. Christner, K. M. Conn, M. U. Nylen, Properties of dissociatively extracted fetal tooth matrix proteins. I. Principal molecular species in developing bovine enamel, J. Biol. Chem,1980, 255: 9760-9768.

[23] S. Habelitz, A. Kullar, S. J. Marshall, P. K. DeBesten, M. Balooch, G. W. Marshall, W. Li, Amelogenin-guided crystal growth on Xuoroapatite glass-ceramics, J. Dent. Res, 2004, 84: 698-702.

[24] Y. Gao, B. W. Ganss, H. KWang, R. E. Itchinga A. Seth, The RING finger protein RNF11 is expressed in bone cells during osteogenesis and is regulated by Ets1. Exp Cell Res, 2005, 304: 127-135. 